Association for Information Systems AIS Electronic Library (AISeL)

CONF-IRM 2017 Proceedings

International Conference on Information Resources

Management (CONF-IRM)

5-1-2017

\title{
Using a Digital Divide Index among Enterprises in the Context of Public Policies in Brazil
}

Érica Souza Siqueira

EAESP/FGV, erica_ssiqueira@hotmail.com

Cesar Alexandre de Souza

FEA/USP

Alexandre F. Barbosa

Cetic.br, alexandre@nic.br

Danilo Senen

EAESP/FGV, danilosenen@gmail.com

Fernando Meirelles

EAESP/FGV, fernando.meirelles@fgv.br

Follow this and additional works at: http://aisel.aisnet.org/confirm2017

\section{Recommended Citation}

Siqueira, Érica Souza; de Souza, Cesar Alexandre; Barbosa, Alexandre F.; Senen, Danilo; and Meirelles, Fernando, "Using a Digital Divide Index among Enterprises in the Context of Public Policies in Brazil" (2017). CONF-IRM 2017 Proceedings. 41.

http://aisel.aisnet.org/confirm2017/41 


\title{
USING A DIGITAL DIVIDE INDEX AMONG ENTERPRISES IN THE Context of Public Policies in Brazil
}

\author{
Érica Souza Siqueira \\ EAESP/FGV \\ erica_ssiqueira@ hotmail.com
Alexandre F. Barbosa
Cetic.br
alexandre@nic.br

\author{
Cesar Alexandre de Souza \\ FEA/USP \\ calesou@usp.br \\ Danilo Senen \\ EAESP/FGV \\ danilosenen@gmail.com
}

\author{
Fernando Meirelles \\ EAESP/FGV \\ fernando.meirelles@ fgv.br
}

\begin{abstract}
The aim of the present paper is to discuss the relevance of an index capable of measuring the digital divide among small and medium enterprises (SMEs) and discuss its importance in the context of public policies. The contention is that the digital divide mainly affects SMEs, and that this phenomenon is related to the low productivity and high mortality rates of these organizations. The methodology for creating the index is replicated here in order to discuss the quality criteria necessary for the index, within the scope of its utility for public managers.
\end{abstract}

\section{Keywords:}

Digital Divide, SMEs, Public Policies, ICT Indicators

\section{Introduction}

Information and communication technologies (ICT) are widely used by enterprises to generate, store and transmit data and information. ICT enables innovations in processes, products, and services. Such innovations can break the cycle of diminishing returns and establish a virtuous cycle of growth and productivity (Biagi, 2016).

Given the potential of ICT to enable innovation, this paper argues that, in accordance with Fong (2009) and Stiakakis et al. (2010), differences in effective ICT use and adoption by enterprises can increase gaps in their development and productivity levels, especially between large and small and medium enterprises (SMEs). To refer to this phenomenon of differences in ICT use, the present article adopts the concept of the "second-order digital divide," which will be explained in more detail in the theoretical framework.

Next, we discuss the importance of public policies to foster ICT use in the business environment with the aim of bridging the digital divide among enterprises, by positing the following research question: What is the relevance of a Digital Divide Index in the policymaking context?

In the business context, ICT has traditionally been studied by means of theories about the adoption and dissemination of innovation, which has produced relevant theoretical and practical contributions, such the study by Alismaili et al. (2016) on the adoption of cloud computing by SMEs. However, in the present article, the focus is not on the phenomenon of 
adoption and dissemination, but on the digital divide, a problem that affects the economic order. In so doing, we hope to help bring together two relevant fields of study in examining the phenomenon under analysis: ICT in organizations and public policies.

\section{The Digital Divide among Enterprises}

In the 1980s and 1990s, the academic literature intensely debated the topic of ICT and its impact on the productivity of enterprises, in the sense of questioning whether ICT actually affects productivity, a discussion that became known as the "productivity paradox" (Brynjolfsson \& Yang, 1996). The present paper is based on the conclusions already reached in the literature, namely, that ICT can directly or indirectly affect productivity. In industries that produce ICT goods and services, such as the software industry, the impact is direct. When ICT is used as input in other businesses, their impact is indirect (Gordon, 2012).

If on the one hand, ICT can impact productivity and enable innovation, on the other, it increases dependency on its use and, furthermore, introduces a new type of disparity, known as the "digital divide." This divide impacts individuals, countries, and enterprises, whether because of lack of access to ICT or inadequate use of these resources to obtain benefits. (Dewan \& Riggins, 2005; Van Dijk, 2006).

The Organization for Economic Co-operation and Development (OECD) defines the digital divide as the gap between individuals, households, businesses, and geographical areas with regard to both opportunities to access ICT and ability to use the Internet to carry out a wide variety of activities (OECD, 2001). In addition to the OECD, other international organizations are concerned with the issue of the digital divide, such as the Digital Opportunity Task Force, which involves the world's eight richest nations (G-8), the World Summit on the Information Society of the United Nations and the World IT Forum of the International Federation for Information Processing ${ }^{1}$ (Avgerou, 2003).

The present study employs the definition of digital divide proposed by Dewan and Riggins (2005). According to these authors, there is a first-order divide, related to acess to ICTs, and a second-order divide, which relates to differences in ICT use among those who already have access to technology. The authors argue that technologies have been increasingly available and affordable, and most participants in any social system now have access to them. From the viewpoint of enterprises, ICT use can provide leverage, making the second-order divide even more significant in this scenario.

In the case of organizations, this phenomenon affects SMEs in particular. The fact that SMEs are not able to enjoy the benefits of ICT in the same way as large enterprises makes them more vulnerable to changes in the financial and competitive conditions of markets. (Wielick \& Arendt, 2010; Arendt 2008).

Specifically in relation to Brazil, the digital divide phenomenon among SMEs is related more to ICT use than ICT access, characterizing a second-order divide. The 2014 edition of the "ICT Enterprises" survey, which is conducted annually by the Brazilian Internet Steering Committee (CGI.br), showed that while most enterprises had computer and Internet access (96\%), only 62\% were present on the Internet with their own websites, and only $29 \%$ reported using an Enterprise Resource Planning (ERP) system to integrate data into a single system

\footnotetext{
${ }^{1}$ See: Dot Force initiative (http:// orgs.tigweb.org), World Summit on the Information Society of the United Nations, International Telecommunications Union (http://www.itu.int/wsis), or World IT Forum of the International Federation for Information Processing (http://www.witfor2016.org).
} 
(CGI, 2015). Another aspect of the survey data that seems important is quality of access: while $55 \%$ of the large enterprises had main connection speeds of more than $10 \mathrm{Mbps}$, this proportion fell to 34\% among SMEs. (CGI, 2015). Different studies have demonstrated the relevance of ICT use for SME management. Terziovski (2010), for instance, showed that the absence of information systems that enable enterprises to monitor their performance is one of the main reasons for SME mortality, followed by informal strategic planning.

In terms of the existing academic literature about the digital divide, two recent studies have shown that this theme is widely debated in the literature. However, greater emphasis is given to the divide among countries and individuals, and there is a dearth of discussion about what occurs among enterprises (Srinuan \& Bohlin, 2011; Bach et al., 2013).

Based on this recognition and conceptualization of the digital divide phenomenon among enterprises, the following sections present examples of public policies for the digital inclusion of enterprises. Then, the authors address the importance of a Digital Divide Index in the context of public policy.

\subsection{Public Policies for ICT and Internet Access in Brazil}

In their paper about factors that contribute to reducing the second-order digital divide, Siqueira et al. (2016) identified that ensuring access to ICT is still essential. In this direction, two national policies in Brazil stand out in terms of facilitating ICT access for Brazilian enterprises. The first is funded by the Brazilian National Development Bank (BNDES), within the scope of the Special Agency for Industrial Financing (FINAME) program, enabling the acquisition of ICT by interested enterprises.

The second policy aims to enable Internet access via the National Broadband Plan (PNBL), created by the Ministry of Communication, with the goal of expanding broadband access not only among end users and individuals, but also among organizations (Souto, Cavalcanti \& Martins, 2010). Regarding the PNBL, Cruz (2014) discussed broadband as a basic condition for the economic inclusion of individuals and enterprises.

\subsection{Information Policies Regarding the Benefits of ICT}

La Rovere (1998) stated that SMEs are excluded because they lack access to information about the benefits and availability of ICT. Similarly, according to Wielicki and Cavalcanti (2006), this phenomenon is associated more with educational issues, training, and ICT knowledge and skills of employees than actual lack of access or financial resources.

Regarding the training of enterprises, their employees, and entrepreneurs, the following initiatives stand out within the context of SMEs:

- Secretary of Science and Technology for Social Inclusion (SECIS) - Supports the popularization of science and the diffusion of technology

- Ministry of Development, Industry, and Foreign Trade - Provides Information and Business Telecenters (TIN), with the mission of teaching digital literacy to entrepreneurs

- Brazilian Service of Support for Micro and Small Enterprises (SEBRAE) - Program to Promote Technology and Information Use in Micro and Small Enterprises (Proimpe).

\subsection{Industrial Policies within the Context of Local Industrial Clusters and Innovation} According to Castells (2000), the new global economic reality of network formation is a trend from which there is no turning back. This author affirms that cooperation among members of 
a network forms structures that facilitate learning processes suited to new digital technologies. Similarly, Lastres and Albagi (1999) stated that ICT enables interconnections between agents within a chain, which fosters ongoing learning in a community and no longer just among individual enterprises. The authors also indicated that the ongoing learning of networks is key to the productive and innovative development of enterprises.

According to Castells (2000) and Lastres and Albagi (1999), the influence of the external environment is very important to ICT adoption. They suggested that participation in local industrial clusters, called "Local Industrial Arrangements (LIAs)" in Brazil, can help stimulate ICT adoption among SMEs. Galdamez et al. (2009) provided the following conceptualization of LIAs: "systems that can be used to promote cooperation among enterprises, ongoing innovation, and sustainable development of small and medium enterprises (SMEs)” (p.3).

In 2003, with the implementation of the Industrial, Technological and Foreign Trade Policy (PITCE), micro, small, and medium enterprises (MSMEs) were given priority in public policies which aimed to fund firms in specific LIAs (Safarti, 2013). Based on these LIAs, government agencies such as BNDES, the Brazilian Trade and Investment Promotion Agency (Apex), the Ministry of Science and Technology, and the Funding Agency for Studies and Research (Finep) support SMEs. According to one author, in 2005, there were 957 LIAs, of which 267 were considered priority (Safarti, 2013).

\section{Indicators and Public Policy}

Indicators are essential to inform policymaking, because they provide elements to guide policymakers' decisions at each step of the policy cycle (Jannuzzi, 2002). Effective public policies require good use of indicators and sound statistics throughout the different steps of the policymaking process (Scott, 2005). Indicators are also essential to measure the effectiveness and impact of policies (Othman, 2005).

The development of indicators as a way to measure a given context can result in political learning, given that by presenting data and information relevant to that context, such measurements can generate political insight (Johnsen, 2005, Howlett, Ramesh \& Perl, 2009). Measuring the characteristics of a given social reality enables the formulation of policies that function as solutions to possible flaws and/or weaknesses of that reality.

Indicators must be capable of presenting relevant information and evidence about aspects of, or changes that occur in, social reality (Jannuzzi, 2002), serving as an operational instrument for monitoring that reality, and formulating and reformulating public policies. Jannuzzi (2002) established that indicators should meet the following criteria: relevance to the discussion of political agendas; present validity in terms of representing reality; having no problems related to validity or statistical significance; being based on reliable data; use of well-defined samples; freedom from systematic data collection errors; presentation of a wide range of coverage, sensitivity to implemented public policies; and being intelligible, updatable, and easily disaggregated according to geographic, demographic and economic variables.

The next section presents three types of measurements of ICT use by organizations: indicators from the Plan of Action of the Information Society in Latin America and the Caribbean (eLAC) of the Economic Commission for Latin America and the Caribbean (ECLAC); the Networked Readiness Index (NRI) of the World Economic Forum; and the Digital Divide 
Index, which construction and composition will be described in the present article. These indicators are presented as the basis of the discussion about how the Digital Divide Index can be used within the scope of policymaking in Brazil.

\subsection{Indicators to Track eLAC Goals}

eLAC is an action plan for the information society developed by the Economic Commission for Latin America and the Caribbean (ECLAC). The plan of action is composed of several goals, but with regard to SMEs, there is a specific objective of increasing ICT access and use. In 2010, the eLAC goal tracking report utilized the following indicators relative to the inclusion of SMEs: access to computers; access to the Internet; portal on the Internet; and use of the Internet distribute products, search for government information and services, provide client services, provide financial services, and sending emails; and use of ERP and customer relationship management (CRM) systems (ECLAC, 2010).

Data from the 2009 survey indicated that nearly 100\% of SMEs had access to computers and the Internet and used the Internet for communication via email. However, when compared with large enterprises, they presented low levels of provision of client services and use of ERPs and CRMs. This data pointed to the presence of a digital divide, which according to ECLAC must be fought against, because in addition to being insufficient, ICT use is unequal among different sectors of the economy and enterprise sizes (ECLAC, 2010, p.70).

However, these indicators were not aggregated into a single measure that could serve as an index, and this hinders comparison among enterprises.

\subsection{Network Readiness Index (NRI)}

The Network Readiness Index (NRI), defined by the World Economic Forum (WEF), evaluates a country's level of readiness to obtain and participate in the benefits of ICT. The index consists of measures related to the environment (infrastructure), readiness (culture, adherence, and processes), and ICT use by society, government, and enterprises of the nation. According to the Global Information Technology Report (GITR), the higher the NRI, the better the country's conditions for development, innovation, competitiveness, and productivity. In the 2009 and 2014 reports, for example, the correlation between NRI and per capita GDP was very high, 0.71 .

In terms of ICT usage among enterprises, a subindex of the NRI specifically captures this dimension, using the following indicators: ICT adoption; capacity to innovate, number of patent applications; Internet use for $\mathrm{B} 2 \mathrm{~B}$; Internet use for $\mathrm{B} 2 \mathrm{C}$; and staff training for ICT, all measured in country level.

When only this subindex related to ICT in enterprises is analyzed, Brazil ranked fifth in relation to other Latin American countries. In comparison with the other four BRICS (Russia, India, China and South Africa), it ranked third. In general terms, Brazil fell from No. 33 to 59 from 2012 to 2016 in the ranking, as shown in Table 1. 


\begin{tabular}{|c|c|c|c|c|c|r|r|r|r|}
\hline \multicolumn{2}{|c|}{2012} & \multicolumn{2}{c|}{2013} & \multicolumn{2}{c|}{2014} & \multicolumn{2}{c|}{2015} & \multicolumn{2}{c|}{2016} \\
\hline Index & Ranking & Index & Ranking & Index & Ranking & Index & Ranking & Index & Ranking \\
\hline 4 & 33 & 3.9 & 34 & 3.9 & 41 & 3.83 & 52 & 3.70 & 59 \\
\hline
\end{tabular}

Table 1 - NRI subindex: ICT use among organizations - Brazil 2012 to 2016

Source: WEF Global Information Technology Report 2016

Two observations can be made here about the usage subindex created by the NRI, regarding sample size and representativeness. In terms of size, with the exception of patent applications, the other indicators were measured by the Executive Opinion Survey, conducted annually by the World Economic Forum in several countries. The survey is used to calculate country competitiveness. In the case of Brazil, 143 executives were interviewed. With regard to the representativeness of interviewed enterprises, even though it was not possible to establish how many small and medium enterprises were included in the 2014 publication, by approximation with the 2011 survey, an estimated $22 \%$ of those interviewed had up to 100 employed persons, $14 \%$ had up to 500 employed persons, and the others had over 500. This leads to the hypothesis that the ICT use index was based mostly on the responses of large enterprises, which could have elevated the value of the index and placed Brazil at a higher ranking. Thus, this index may not adequately reflect the reality of SMEs in Brazil.

\subsection{Digital Divide Index}

Siqueira et al. (2014) proposed a Digital Divide Index to measure the intensity of ICT use by SMEs, based on the argument that use, and not access, is the most important aspect when studying the digital divide among enterprises in Brazil. The measure is based on the model proposed by Zwicker et al. (2007), in which ICT use in organizations is composed of the following dimensions: a) ICT use for the enterprise's internal (vertical and horizontal) and external integration; b) ICT use to support decision-making; and c) ICT use to generate knowledge and innovation.

Therefore, the aim of the present study was to analyze the validity of the Digital Divide Index proposed by Siqueira et al. (2014) in the context of public policies, using the criteria listed by Jannuzzi (2002). This article is an integration of a group of other studies about the digital divide, in which the authors: a) demonstrated how the index was created (Siqueira et al., 2014); b) explored sectoral differences (Siqueira et al., 2015b); c) validated the statistical technique employed in data analysis (Siqueira et al., 2015a); and d) found factors that contribute to bridging the divide (Siqueira et al., 2016), using the data from the 2013 edition of the survey. The next section explains the methodology used to create the index, followed by a discussion about its importance.

\section{Methodological Aspects}

The digital divide index was initially proposed and developed by Siqueira et al. (2014) using microdata from "ICT Enterprises" survey conducted in 2011 by CGI.br. For the purposes of this article, the index was replicated using the microdata base from the survey's 2014 edition. This section presents the conceptual model, in addition to the steps taken to replicate the index, which took place in three stages, as described below.

\subsection{Data Selection}

The index was created using a subsample of the microdata obtained in the national CGI.br ICT Enterprises survey, according to rigorous criteria for sampling design and selection. In the present article, the index was replicated by using data from the 2014 survey, which included interviews with 7,198 small, medium, and large enterprises. To compose the 
subsample, only SMEs were considered, so the sample of this universe consisted of 5,346 enterprises. We considered as SMEs companies ranging from 10 to 249 employees. Enterprises that did not respond or responded "does not know" to any of the questions representing the variables used to calculate the ICT use index were excluded. The final sample consisted of 3,231 small and medium enterprises.

\subsection{Statistical Method}

Based on the conceptual model of ICT use, and using structural equation modeling, the measurement model shown in Figure 1 was obtained. This model was replicated using SmartPLS software, obtaining a factorial score for each enterprise for each dimension of ICT use. After calculating the scores for each dimension, a factorial score the second-order index (ICT use) was also obtained (the weighted sum of the answers in each dimension). Finally, the scores for each subdimension, as well as the scores for the ICT use index were transformed into an interval between 0 and 1 .

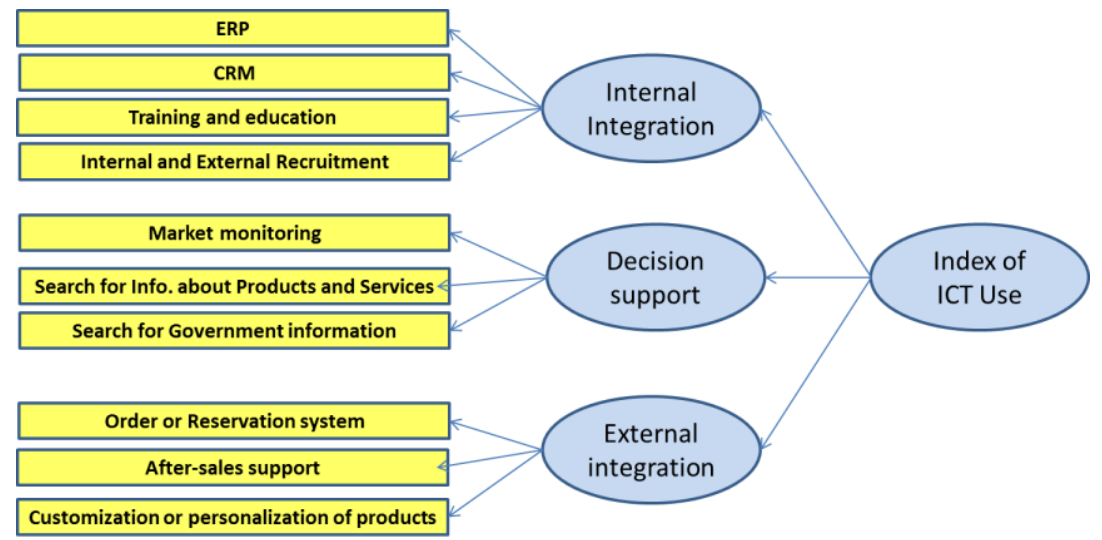

Figure 1 - ICT use index obtained from the analysis of ICT Enterprises survey microdata

\subsection{Quality of the Model}

The indicators used here to assess the PLS model were: composite reliability (CR), which must be greater than 0.07; convergent validity, assessed by the mean average extracted from the concept (AVE), which must be higher than 0.05; factor loading analysis, which must be significant and/or higher than 0.07; and discriminant validity, which can be assessed using cross-loadings (Hair Jr. et al., 2014).

\section{Data Analysis}

As an example, Table 2 contains the first four enterprises of the sample, demonstrating the factorial scores for each dimension of ICT use, in addition to a score for ICT use.

\begin{tabular}{|c|c|c|c|c|c|c|}
\hline $\begin{array}{c}\text { Enterprise } \\
\text { ID }\end{array}$ & Sector & $\begin{array}{c}\text { Size } \\
(\mathbf{e m p .})\end{array}$ & $\begin{array}{c}\text { External } \\
\text { Integration }\end{array}$ & $\begin{array}{c}\text { Internal } \\
\text { Integration }\end{array}$ & $\begin{array}{c}\text { Decision } \\
\text { Support }\end{array}$ & $\begin{array}{c}\text { ICT } \\
\text { Use }\end{array}$ \\
\hline 1 & Manufacturing & $20-49$ & 0.000 & 0.253 & 0.744 & 0.393 \\
\hline 2 & Transportation & $20-49$ & 0.310 & 0.253 & 0.499 & 0.354 \\
\hline 3 & Real State & $20-49$ & 0.000 & 0.000 & 0.754 & 0.287 \\
\hline 4 & $\begin{array}{c}\text { Arts \& } \\
\text { Entertainment }\end{array}$ & $20-49$ & 0.000 & 0.000 & 0.754 & 0.287 \\
\hline
\end{tabular}

Table 2 - Examples of Enterprises and Indexes' Scores

Table 3 presents the values for the mean, standard deviation and interquartile ranges, considering the entire sample of 3,213 enterprises. To analyze the digital divide among SMEs, 
the enterprises were classified as: a) excluded; b) partially excluded; c) partially included; and d) included, considering the quartiles obtained by analyzing the use index score. Thus, enterprises with scores lower than 0.0459 (first quartile) are classified as excluded, and those with scores higher than 0.743 (third quartile) are classified as included.

\begin{tabular}{|l|l|l|l|l|l|l|}
\hline & $\mathbf{N}$ & Mean & Std Deviation & $\mathbf{1}^{\text {st }}$ Quartile & Median & 3 $^{\text {rd }}$ Quartile \\
\hline 2014 Index & 3,231 & 0.591 & 0.199 & 0.459 & 0.592 & 0.743 \\
\hline
\end{tabular}

Table 3: Distribution by size

Lastly, Figure 2 illustrates the phenomenon of the second-level divide, as the concentration of excluded enterprises occurring among smaller enterprises.

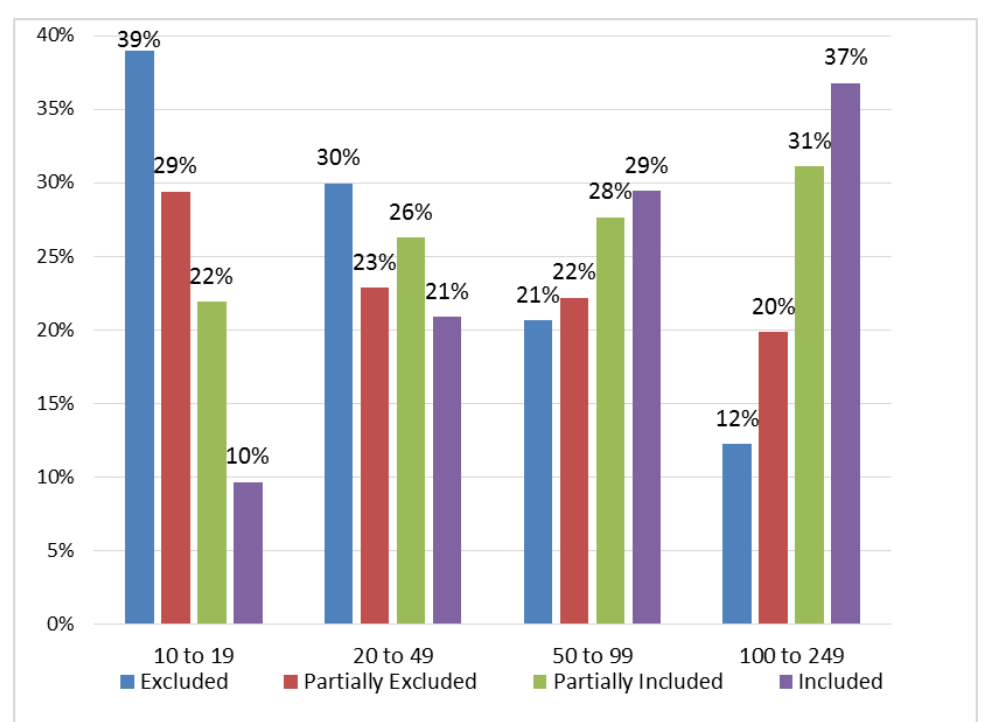

Figure 2 -Digital Divide distribution among enterprises by size (qty. of employees)

Figure 3 demonstrates the evolution of the ICT use index over three editions of the ICT Enterprises survey (2011, 2013 and 2014), demonstrating the evolution for each size and overall evolution. The index can showed evolution in all sizes of enterprises, and at the same time, was able to detected movement such as that among enterprises with 100 to 249 employed persons, which expanded their ICT use more rapidly than the other enterprises between 2011 and 2013 .

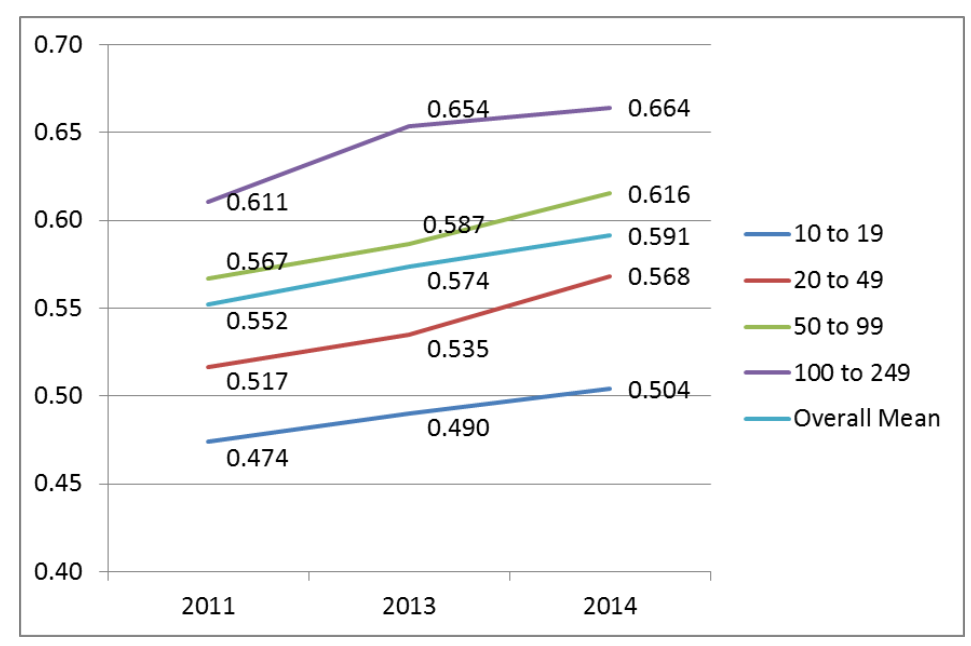

Figure 3-Means of ICT use index by year and enterprise size (qty. of employees) 


\section{Discussion and Final Remarks}

The main argument presented by this article is the need to consider differences in ICT use among enterprises as an issue related to the digital divide. From this perspective, the digital divide is related to low productivity rates and high mortality rates of enterprises. Based on this understanding, public policies should be created to bridge this gap.

Regarding public policies, this article suggests that the proposed index could be more interesting than the NRI and the eLAC indicators. For the NRI, ICT use by organizations is calculated based on a sample with few enterprises, and this index does not control the representativeness of the sample. The eLAC is composed of indicators that were not used to create an index. The digital divide index is based on usage indicators to calculate first-order indexes: ICT use to support decision making, internal integration, and external integration, according the theoretical model of use. Based on these indexes, the overall ICT use index was calculated, which we called the Digital Divide Index.

We argue that the digital divide index meets the quality criteria proposed by Januzzi (2002), as shown in Figure 4. Therefore, it can be considered as relevant to the creation and assessment of public policies that are directed toward the digital inclusion of SMEs, both because it clarifies the phenomenon, as shown in Figure 4, and meets these criteria.

\begin{tabular}{|l|l|}
\hline \multicolumn{1}{|c|}{\begin{tabular}{c}
\multicolumn{1}{c|}{ Crite rion } \\
(Jannuzzi, 2002)
\end{tabular}} & \multicolumn{1}{|c|}{ Digital Divide Index } \\
\hline $\begin{array}{l}\text { Relevance to the discussion of } \\
\text { political agendas }\end{array}$ & $\begin{array}{l}\text { Relevance was initially presented in terms of concern (national } \\
\text { and international) about the topic of the digital divide and } \\
\text { economic development. }\end{array}$ \\
\hline $\begin{array}{l}\text { Validity to represent reality } \\
\text { (validity problems and statistical } \\
\text { significance) }\end{array}$ & $\begin{array}{l}\text { The index was initially constructed based on a sample of 2,000 } \\
\text { SMEs, and is being replicated with even larger samples. See: } \\
\text { Siqueira et al. (2014, 2015a, 2015b, 2016). }\end{array}$ \\
\hline $\begin{array}{l}\text { Data Reliability (sampling } \\
\text { problems, systematic data } \\
\text { gathering errors) }\end{array}$ & $\begin{array}{l}\text { The indicator was constructed with the microdata from a survey } \\
\text { conducted annually by CGI.br, an organization that follows a } \\
\text { criterions sampling process, with the goal of enabling } \\
\text { generalization. }\end{array}$ \\
\hline $\begin{array}{l}\text { Range of coverage } \\
\text { The data is collected throughout Brazil, in all regions and states, } \\
\text { according to sampling criteria, to allow generalization. }\end{array}$ \\
\hline Sensitive to existing policies & $\begin{array}{l}\text { The index should reflect, to some degree, the results of existing } \\
\text { policies to incentivize and diffuse innovation and technology } \\
\text { among SMEs. }\end{array}$ \\
\hline $\begin{array}{l}\text { Intelligible (problem of using very } \\
\text { complex indicators, revealing } \\
\text { technocratic abuse). }\end{array}$ & $\begin{array}{l}\text { The index proposed here ranges from 0 to 1. The lower the score } \\
\text { obtained on the index, the less intense ICT use in a given SME, } \\
\text { and therefore, the more excluded the enterprise. }\end{array}$ \\
\hline Updatable & The data is collected annually with increasingly broader samples. \\
\hline $\begin{array}{l}\text { Can be disaggregated by } \\
\text { geographic, demographic and } \\
\text { economic variables. }\end{array}$ & $\begin{array}{l}\text { The index proposed here can be disaggregated by sector business } \\
\text { sector, region/municipality, revenue, and size. }\end{array}$ \\
\hline $\begin{array}{l}\text { Historicity (problems related to } \\
\text { the disposition of compatible } \\
\text { series). }\end{array}$ & $\begin{array}{l}\text { Data collection allows for a study of the index's evolution, since } \\
\text { the information is compatible with data already collected over } \\
\text { the last ten years. }\end{array}$ \\
\hline
\end{tabular}

Figure 4-Jannuzzi's quality criteria and the digital divide index 


\section{REFERENCES}

Alismaili, S., Li, M., Shen, J., \& He, Q. (2016). A Multi Perspective Approach for Understanding the Determinants of Cloud Computing Adoption among Australian SMEs. Procedings of the Australasian Conference on Information Systems, Adelaide, Australia.

Arendt, L. (2008). Barriers to ICT adoption in SMEs: how to bridge the digital divide? Journal of Systems and Information Technology, 10(2), 93-108.

Avgerou, C. (2003). The link between ICT and economic growth in the discourse of development. In Organizational information systems in the context of globalization. US, Springer, 373-386.

Bach, M. P., Zoroja, J., \& Vukšić, V. B. (2013). Review of corporate digital divide research: A decadal analysis (2003-2012). International Journal of Information Systems and Project Management, 1(4), 41-55.

Biagi, F. (2013). ICT and Productivity: A Review of the Literature. JRC Institute for Prospective Technological Studies, Digital Economy Working Paper, 9.

Brazilian Institute of Geography and Statistics - IBGE. (2010). Estatísticas do Cadastro Central de Empresas. Brasilia, IBGE.

Brazilian Internet Steering Committee - CGI.br. (2015). Survey on the Use of Information and Communication Technologies in Brazilian Enterprises - ICT Enterprises 2014. Coord. Alexandre F. Barbosa. São Paulo, CGI.br.

Brynjolfsson, E., \& Yang, S. (1996). Information technology and productivity: a review of the literature. Advances in Computers, 43, 179-214.

Castells, M. (2000). A sociedade em rede: a era da informação: economia e cultura, v.1. São Paulo, Ed. Paz e Terra.

Centro de Gestão de Estudo Estratégicos. CGEE. (2010). Avaliação do programa de apoio a implantação e modernização de centros vocacionais tecnológicos (CVT). Série documentos técnicos, n.2, Brasilia.

Dewan, S.; Riggins, F. J. (2005). The digital divide: Current and future research directions. Journal of the Association for Information Systems, 6(12), 298-337.

ECLAC (2010). Monitoring of the Plan of Action eLAC2010: Advances and challenges of the information society in Latin America and the Caribbean. ECLAC.

Fong, M. W. L. (2009). Digital Divide: The Case of Developing Countries. Issues in Informing Science and Information Technology, v, 6.

Galdámez, E. V. C., Carpinetti, L. C. R., \& Gerolamo, M. C. (2009). Proposta de um sistema de avaliação do desempenho para arranjos produtivos locais. Gestão \& Produção, 16(1), 133-151.

Gordon R.J. (2012), "Is the U.S. Economy Growth Over? Faltering Innovation Confronts the Six Headwinds", NBER Working Paper No. 18315

Hair Jr., J. F., Hult, G. T. M., Ringle, C. M., \& Sarstedt, M.(2014) A Primer on Partial Least Squares Structural Equation Modeling. Thousand Oaks: Sage.

Howlett, M.; Ramesh, M.; Perl, A. (2009). Studying Public Policy, 3rd ed. Canada, Oxford University Press. 
Jannuzzi, P. M. (2002). Considerações sobre o uso, mau uso e abuso dos indicadores sociais na formulação e avaliação de políticas públicas municipais. Revista de Administração Pública, 36(1), 51-72.

Johnsen, A. (2005). What does 25 years of experience tell us about the state of performance measurement in public policy and management? Public Money and Management, 25(1), 917.

La Rovere, R. (1998). Diffusion of information technologies and changes in the telecommunications sector: The case of Brazilian small- and medium-sized enterprises. Information Technology \& People, 11(3), 194-206.

Lastres, H. M., \& Albagli, S. (1999). Informação e globalização na era do conhecimento. Rio de Janeiro, Ed. Campus.

OECD. Understanding the Digital Divide (2001). Available at: < https://www.oecd.org/sti/1888451.pdf > . Accessed on: Sep 15, 2016.

Othman, A. (2005). The Role of Statistics in Factual-Based Policy-Making. Journal of the Department of StatisTIC, Malaysia, v. 1, 2005, p. 1-16.

Safarti, G. (2013). Estágios de desenvolvimento econômico e políticas públicas de empreendedorismo e de micro, pequenas e médias empresas (MPME) em perspectiva comparada: os casos do Brasil, do Canadá, do Chile, da Irlanda e da Itália. Rev. Adm. Pública, 47(1), 25-48.

Scott, C. (2005). Measuring Up to the Measurement Problem: the role of statistics in evidence-based policy-making. Available at: <http://www.paris21.org/sites/ default/files/1509.pdf>. Accessed on: Dec 30, 2016.

Siqueira, É. S; Souza, C.A; Chagas, V. (2014). Uso das TIC nas Pequenas e Médias empresas Brasileiras: construção de um índice de uso utilizando dados da pesquisa TIC Empresas e modelagem de equações estruturais. Proceedings of the Seminários em Administração (SemeAd 2014), São Paulo, Brazil.

Siqueira, É. S.; Araujo, M. H.; Souza, C. A.; Reinhard, N. (2015a). Análise Multivariada com Dados Binários e Sua Potencial Aplicação na Área de Tecnologia da Informação e Comunicação. Proceedings of the Encontro de Administração da Informação (EnADI 2015), Brasilia, Brazil.

Siqueira, É. S.; Souza, C. A.; \& Reinhard, N. (2015b). Digital Divide in Small and Medium Business: an Analysis of Sector Differences in Brazilian Companies based on Data from a Nationwide Survey. Proceedings of the 2015 International Conference on Information Systems (Conf-IRM), Ottawa, Canada.

Siqueira, É.; Souza, C. A. (2016). Exclusão Digital das Pequenas e Médias Empresas Brasileiras-um olhar pela teoria de adoção das Tecnologias de Informação e Comunicação. Proceedings of the 2016 International Conference on Information Systems (Conf-IRM), Cape Town, South Africa.

Souto. Á. A.; Cavalcanti, D. B.; Martins, R. P. (Org). Um plano nacional para banda larga: o Brasil em alta velocidade. Brasilia: Ministério das Comunicações.

Srinuan, C., \& Bohlin, E. (2011). Understanding the digital divide: A literature survey and ways forward. Proceedings of the 22nd European Regional Conference of the International Telecommunications Society (ITS2011), Budapest, Hungary. 
Stiakakis, E., Kariotellis, P., \& Vlachopoulou, M. (2009). From the digital divide to digital inequality: A secondary research in the European Union. International Conference on $e$ Democracy, Berlin, Springer Berlin Heidelberg, 43-54.

Wielicki, T., \& Arendt, L. (2010). A knowledge-driven shift in perception of ICT implementation barriers: Comparative study of US and European SMEs. Journal of Information Science, 36(2), 162-174.

Wielicki, T. R., \& Cavalcanti, G. (2006). Study of Digital Divide: Measuring ICT Utilization and Implementation Barriers Among SMEs of Central California. Proceedings of the International Conference on Business Information Systems (BIS), 85, 277-294.

Van Dijk, J. A. (2006). Digital divide research, achievements and shortcomings. Poetics, 34(4), 221-235.

Zwicker, R.; Souza, C. A.; Vidal, A. G.; Siqueira, J. O. (2007). Grau de Informatização de Empresas: Um modelo estrutural aplicado ao setor industrial do estado de São Paulo. RAE Eletrônica, 6(2).

Terziovski, M. (2010). Innovation practice and its performance implications in small and medium enterprises (SMEs) in the manufacturing sector: a resource-based review. Strategic Management Journal, 31(8), 892-902. 